\title{
A Novel Laboratory Marker for Hepatosteatosis: Mean Platelet Volume to Lymphocyte Count Ratio
}

\author{
Hepatosteatozda Yeni Bir Laboratuvar Belirteci: \\ Ortalama Trombosit Hacmi/Lenfosit Oranı
}

\section{Özgün Araştrrma Research Article}

Received/Geliş: 02.03.2020 Accepted/Kabul: 05.03.2020 Published Online: 29.04.2021

Satılmış Bilgin Abant Izzet Baysal University Hospital, Department of Internal Medicine, Bolu - Türkiye drsatilmisbilgin@gmail.com ORCID: 0000-0003-2811-0052

Ö. Kurtkulagi 0000-0002-4162-5563 Abant Izzet Baysal University Hospital, Department of Internal Medicine, Bolu, Türkiye

Cite as: Bilgin S, Kurtkulagi O. A novel laboratory marker for hepatosteatosis: Mean platelet volume to lymphocyte count ratio. Tepecik let volume to lymphocyte count ratio. Tepeci
Egit. ve Arașt. Hast. Dergisi. 2021;31(1):80-3.

\author{
Satilmis Bilgin $\odot$, Ozge Kurtkulagi $\odot$
}

Öz

Amaç: Hepatosteatosis (HS) is defined as accumulation of fat in liver reaching to an amount of at least $5 \%$ of liver weight. Not just mean platelet volume (MPV), but also MPV to lymphocyte ratio (MPVLR) has been introduced as a marker in inflammatory and metabolic conditions. We aimed to compare MPVLR values of patients with hepatosteatosis with those of healthy controls. We also investigated the correlation between CRP and MPVLR

Methods: The data of the patients with HS who were admitted to internal medicine outpatient clinics of our institution between 2018 December and 2019 December were enrolled into the study. The MPVLR were calculated using MPV/lymphocyte formula.

Results: The median MPVLRs of the HS and control groups were 4.3\% (2.1) and 3.6\% (1.7), respectively ( $p<0.001)$. The median CRP levels of the HS and control groups were $3.6(4.9) \mathrm{mg} / \mathrm{L}$ and $0.4(0.2) \mathrm{mg} / \mathrm{L}$, respectively $(p<0.001)$. The MPVLR was positively and strongly correlated with CRP $(r=0.64, p<0.001)$. However, MPVLR and the biochemical parameters; LDL-cholesterol, ALT and triglyceride were not correlated at all..

Conclusion: We suggest that elevated MPVLR should alert physicians for possible hepatosteatosis in a population without comorbidities. Positive and strong correlation between CRP and MPVLR should also prompt use of MPVLR as a reliable inflammatory predictor.

Anahtar kelimeler: Mean platelet volume to lymphocyte ratio, hepatosteatosis, inflammation

\section{ABSTRACT}

Objective: Hepatosteatoz (HS), karaciğerde en az \%5 kuru ağırlığa denk gelecek șekilde yağ birikmesidir. Sadece Ortalama trombosit hacmi (MPV) değil, aynı zamanda ortalama trombosit hacmi/lenfosit oranı (MPVLR) metabolik ve enflamatuvar durumların bir belirteci olarak bildirilmektedir. Bu çalışmamızda hepatosteatozlu hastaların MPVLR değerini, sağııkı kontrol grubuyla karşılaştırmayı amaçladık. Ayrıca CRP ile MPVLR arasındaki korelasyonu araştırdık.

Yöntem: Kurumumuz iç hastalıkları polikliniklerine 2018 Aralık-2019 Aralık tarihleri arasında başvuran HS'lu hastalar çalışmaya alındı. MPVLR, MPV/Lenfosit formülü ile hesaplandı.

Bulgular: HS ve kontrol gruplarının medyan MPVLR değeri sırasıyla \%4.3 (2.1) ve \%3.6 (1.7) idi ( $p<0.001)$. HS ve kontrol gruplarının medyan CRP değeri sırasıyla 3.6 (4.9) $\mathrm{mg} / \mathrm{L}$ ve $0.4(0.2) \mathrm{mg} / \mathrm{L}$ idi $(p<0.001)$. MPVLR, CRP ile pozitif ve güçlü bir korelasyona sahipti $(r=0.64, p<0.001)$. Buna karşın, MPVLR ile LDL kolesterol, ALT ve trigliserit arasinda korelasyon yoktu.

Sonuç: Komorbiditesi bulunmayan HS'lu hastalarda artmış MPVLR değeri, hekimler için HS açısından uyarıcı olmalıdır. CRP ile MPVLR arasındaki güçlü pozitif korelasyon, MPVLR'nin de güvenilir bir inflamatuvar belirteç olduğunu düşündürmektedir.

Keywords: Ortalama trombosit hacmi lenfosit oranı, hepatosteatoz, inflamasyon

(C) Telif hakkı TC. Să̆lık Bakanlığı i̇zmir Tepecik Eğjit. ve Arast. Hastanesi. Logos Tip Yayınclık tarafindan yayınlanmaktadır.

Bu dergide yayınlanan bütün makaleler Creative Commons Atf-GayriTicari 4.0 Uluslararası Lisansı ile lisanslanmıştr.

(c) Copyright Association of Publication of the T.C. Ministry of Health İmir Tepecik Education and Research Hospital.

This journal published by Logos Medical Publishing.

Licenced by Creative Commons Attribution-NonCommercial 4.0 International (CC BY) 


\section{INTRODUCTION}

Hepatosteatosis (HS) is defined as an accumulation of fat in liver for an amount of at least $5 \%$ of liver weight ${ }^{(1)}$. Inflammation, hepatic dysfunction and non-alcoholic fatty liver disease may be caused by hepatic accumulation of lipids (1). Hepatosteatosis induced inflammation may be associated with a metabolic disturbance, such as, obesity, type 2 diabetes mellitus and metabolic syndrome.

The most frequently studied inflammatory marker in inflammatory conditions is C-reactive protein (CRP) (2). However, in recent studies, several indices of routine hemogram tests have been proposed as inflammatory markers in various conditions. One of these indices is mean platelet volume (MPV), which has been related with many inflammatory and metabolic diseases ${ }^{(3-16)}$.

Not just MPV, but also MPV to lymphocyte ratio (MPVLR) has been introduced as a marker in inflammatory and metabolic conditions (17-19).

In the present retrospective study, it has been aimed to observe MPVLR values of patients with hepatosteatosis and to compare them with those of healthy controls. We also aimed to investigate whether CRP and MPVLR were correlated with each other in study population.

\section{MATERIAL and METHODS}

The study was conducted in Internal Medicine clinics of Abant Izzet Baysal University Hospital after approval of the study protocol by local ethics committee (approval id: 2019/297). The data of the patients with HS who were admitted to internal medicine outpatient clinics of our institution between 2018 December and 2019 December were enrolled to the study. The diagnosis of HS was established with sonographic examination in all participants. The subjects that visited our clinic for routine check-up and defined as healthy individuals were enrolled as the control group. The patients with a history of recent trauma or surgical operation, inflammatory conditions, acute infectious diseases, chronic renal failure, cardiac diseases, diabetes mellitus, active neoplastic diseases and patients on medical treatment that could interfere with platelet functions (i.e. aspirin, clopidogrel) were excluded from the study. Pregnant women and subjects younger than 18 years of age were also excluded.

All hemogram tests were held within 15 minutes after venous blood sampling. Hemogram analysis was done with automatic analyzer of LH 780 model of Beckman Coulter device (Beckman Coulter In.; Bre CA, USA). Original kits of the manufacturer that contain constant amount of anticoagulant (EDTA) were used in laboratory analyses.

Age, sex, data about additional conditions, sonographic findings of liver, and laboratory test results were obtained and recorded from the institutional database and patients' files. Leukocyte (WBC) and lymphocyte (Lym) counts, hemoglobin ( $\mathrm{Hb})$, hematocrit $(\mathrm{Htc})$, platelet counts (PLT) and MPV values were noted. The MPVLR were calculated with MPV/ Lym formula. Biochemical parameters of the participants, such as, low- density lipoprotein (LDL)- cholesterol, triglyceride, alanine transaminase (ALT), and CRP were also analyzed.

Statistical analyses were conducted using SPSS software. (SPSS 15.0; SPSS Inc., Chicago, IL, USA). KruskalWallis test was used to determine whether variables had normal distribution or not. Comparisons of variables with normal distribution were conducted with t-test and expressed as mean \pm standard deviation. Comparisons of variables without normal distribution were performed with Mann-Whitney $U$ test and expressed as median (interquartile range: IQR). Categorical variables were compared in study groups using chi-square test and expressed as numbers and percentages. Correlations between MPVLR and other 
study parameters were investigated with Pearson's correlation analysis test. $\mathrm{P}<0.05$ was accepted as the level of statistical significance.

\section{RESULTS}

Study population was consisted of 147 subjects including 73 in HS and 74 in control groups. Patients with HS were older than the control subjects (44.7 \pm 13.1 vs. $39.7 \pm 8.9$ years, respectively). The age difference between HS and control groups was statistically significant $(p=0.01)$.

Thirty six of 73 patients in HS group and 45 of 74 subjects in control group were male, while 37 of 73 patients in HS group and 29 of 74 subjects in control group were female. The distribution of male, and female participants of in the study and control groups was not statistically different $(p=0.16)$.

Leukocyte counts, PLT, Hb and Htc values of the HS group were not different from those of control subjects (all $p$ values $>0.05$ ).

As expected, ALT ( $p=0.002)$, LDL-cholesterol $(p<0.001)$ and triglyceride $(p=0.01$ ) levels of the HS group were significantly higher than those of the control group. The median MPVLR levels of the HS and control groups were $4.3(2.1) \%$ and 3.6 (1.7) \%, respectively

Table 1. Comparison of the data of the study and control groups.

\begin{tabular}{|c|c|c|c|c|}
\hline & & $\begin{array}{c}\text { HS } \\
\text { Group }\end{array}$ & Control Group & p \\
\hline \multirow[t]{3}{*}{ Sex } & Male (n, \%) & 36 (49\%) & 45 (61\%) & 0.16 \\
\hline & Female (n, \%) & $37(51 \%)$ & $29(39 \%)$ & \\
\hline & & \multicolumn{2}{|c|}{ Mean $\pm S D$} & \\
\hline \multirow{3}{*}{\multicolumn{2}{|c|}{$\begin{array}{l}\text { Age (years) } \\
\mathrm{Hb}(\mathrm{g} / \mathrm{dL}) \\
\mathrm{Htc}(\%)\end{array}$}} & $44.7 \pm 13.1$ & $39.7 \pm 8.9$ & 0.01 \\
\hline & & $14.7 \pm 1.2$ & $15 \pm 1.3$ & 0.22 \\
\hline & & $43.3 \pm 3.4$ & $44 \pm 3.8$ & 0.20 \\
\hline & & \multicolumn{2}{|c|}{ Median (IQR) } & \\
\hline \multicolumn{2}{|c|}{$\mathrm{WBC}\left(\mathrm{k} / \mathrm{mm}^{3}\right)$} & $7(1.7)$ & $7(2.6)$ & 0.11 \\
\hline \multicolumn{2}{|c|}{$\mathrm{PLT}\left(\mathrm{k} / \mathrm{mm}^{3}\right)$} & $242(101)$ & $251(70)$ & 0.42 \\
\hline \multicolumn{2}{|c|}{ MPVLR (\%) } & $4.3(2.1)$ & $3.6(1.7)$ & $<0.001$ \\
\hline \multicolumn{2}{|c|}{ CRP (mg/L) } & $3.6(4.9)$ & $0.4(0.2)$ & $<0.001$ \\
\hline \multicolumn{2}{|c|}{$\operatorname{ALT}(U / L)$} & $39(34)$ & $29(18)$ & 0.002 \\
\hline \multicolumn{2}{|c|}{ LDL-cholesterol (mg/dL) } & $124(20)$ & $119(64)$ & $<0.001$ \\
\hline \multicolumn{2}{|c|}{ Triglyceride (mg/dL) } & $137(53)$ & $128(50)$ & 0.01 \\
\hline
\end{tabular}

$(p<0.001)$. The median CRP levels of the HS and control groups were $3.6(4.9) \mathrm{mg} / \mathrm{L}$ and $0.4(0.2) \mathrm{mg} / \mathrm{L}$, respectively $(p<0.001)$.

The MPVLR was positively and strongly correlated with CRP ( $r=0.64, p<0.001)$. However, there were no correlations between MPVLR and the biochemical parameters; LDL-cholesterol, ALT and triglyceride.

Data of HS and control groups are summarized in Table 1.

\section{DISCUSSION}

As significant outcomes of the present study, statistically higher MPVLR levels in HS patients than those in controls, and strong positive correlation between MPVLR and CRP in the study population were detected.

Both MPV and MPVLR have been shown to be associated with metabolic and inflammatory diseases in medical literature. Vizioli et al. showed that increased MPV should be a risk and prognostic factor for cardiac conditions ${ }^{(14)}$. Consequently, Chu et al reported in a meta-analysis that elevated MPV levels could be a predictor of cardiovascular risk ${ }^{(8)}$. Recent studies are focused on the role of MPVLR in inflammatory and metabolic diseases. For instance, in a recent study, the association between MPVLR and type 2 diabetes mellitus was observed and significantly higher MPVLR levels were reported in diabetic subjects compared to healthy controls ${ }^{(19)}$. In another study, authors studied MPVLR levels of type 2 diabetic subjects with or without diabetic nephropathy and reported that MPVLR of diabetics with nephropathy was significantly elevated than those without ${ }^{(17)}$. Moreover, MPVLR is also suggested to be positively correlated with glycated $\mathrm{Hb}(\mathrm{HbA} 1 \mathrm{c})$ in patients with type 2 diabetes mellitus ${ }^{(19)}$. Moreover, high MPVLR levels have been linked to poor cardiac status in diabetic subjects. Hudzik et al. reported that diabetic patients with elevated MPVLR have worse cardiac outcome compared to the diabetic 
subjects with lower MPVLR levels ${ }^{(20)}$.

Hepatosteatosis is considered as a low burden inflammatory process. Inflammatory molecules such as interleukins may interfere with thrombopoiesis in bone marrow and stimulate production of larger platelets with greater dimensions. Indeed, increased serum levels of insulin, as seen in type 2 diabetes mellitus, was suggested to be responsible for the production of larger platelets from precursor cells (21). These larger platelets might be responsible for elevated MPV and thus, elevated MPVLR levels in circulation, as reported in the present study.

There are two main limitations of the present study. First, relatively small study population and second, retrospective study design, which all could make our results difficult to interpret. However, to the best of our knowledge, this study is the first report in the literature that pointed out an association between MPVLR levels and hepatosteatosis.

\section{CONCLUSION}

We suggest that elevated MPVLR should alert physicians for possible hepatosteatosis in population without comorbidities. Positive and strong correlation between CRP and MPVLR should also prompt use of MPVLR as a reliable inflammatory predictor.

\section{Ethics Committee Approval: Bolu Abant İzzet Baysal} University Clinical Research Ethics Committee approval was obtained (05.12.2019/297).

Conflict of Interest: None to declare.

Funding: None received.

Informed Consent: None to declare.

\section{REFERENCES}

1. Nassir F, Rector RS, Hammoud GM, Ibdah JA. Pathogenesis and Prevention of Hepatic Steatosis. Gastroenterology \& Hepatology. 2015;11:167-75.

2. Vermeire S, Van Assche G, Rutgeerts P. C-reactive protein as a marker for inflammatory bowel disease. Inflammatory Bowel Diseases. 2004;10:661-5. [CrossRef]

3. Sit M, Aktas G, Yilmaz EE, Hakyemez IN, Alcelik A, Kucukbayrak
A. Platelet parameters in hepatic hydatid cysts. International Journal of Inflammation. 2013;2013:593273. [CrossRef]

4. Kapsoritakis AN, Koukourakis MI, Sfiridaki A, et al. Mean platelet volume: a useful marker of inflammatory bowel disease activity. The American Journal of Gastroenterology 2001;96:776-81. [CrossRef]

5. Aktas G, Cakiroglu B, Sit M, et al. Mean platelet volume: a simple indicator of chronic prostatitis. Acta Medica Mediterranea. 2013;29:551-4.

6. Ulasli SS, Ozyurek BA, Yilmaz EB, Ulubay G. Mean platelet volume as an inflammatory marker in acute exacerbation of chronic obstructive pulmonary disease. Polskie Archiwum Medycyny Wewnetrznej. 2012;122:284-90. [CrossRef]

7. Aktas G, Sit M, Tekce H, et al. Mean platelet volume in nasal polyps. The West Indian Medical Journal. 2013;62:515-8. [CrossRef]

8. Chu SG, Becker RC, Berger PB, et al. Mean platelet volume as a predictor of cardiovascular risk: a systematic review and meta-analysis. Journal of thrombosis and haemostasis: JTH. 2010;8:148-56. [CrossRef]

9. Cakir L, Aktas G, Enginyurt O, Cakir SA. Mean platelet volume increases in type 2 diabetes mellitus independent of $\mathrm{HbA} 1 \mathrm{C}$ level. Acta Medica Mediterranea. 2014;30:425-8.

10. Gasparyan AY, Stavropoulos-Kalinoglou A, Toms TE, Douglas KM, Kitas GD. Association of mean platelet volume with hypertension in rheumatoid arthritis. Inflammation \& Allergy Drug Targets. 2010;9:45-50. [CrossRef]

11. Aktas G, Alcelik A, Tekce BK, Tekelioglu V, Sit M, Savli H. Red cell distribution width and mean platelet volume in patients with irritable bowel syndrome. Przeglad Gastroenterologiczny. 2014;9:160-3. [CrossRef]

12. Jaremo $P$, Sandberg-Gertzen $H$. Platelet density and size in inflammatory bowel disease. Thrombosis and Haemostasis. 1996;75:560-1. [CrossRef]

13. Cakir L, Aktas G, Mercimek OB, Enginyurt O, Kaya Y, Mercimek $\mathrm{K}$. Are red cell distribution width and mean platelet volume associated with rheumatoid arthritis? 2016.

14. Vizioli L, Muscari S, Muscari A. The relationship of mean platelet volume with the risk and prognosis of cardiovascular diseases. International Journal of Clinical Practice. 2009;63:1509-15. [CrossRef]

15. Aktas G, Kocak MZ, Duman TT, et al. Mean Platelet Volume (MPV) as an inflammatory marker in type 2 diabetes mellitus and obesity. Bali Medical Journal. 2018;7:650-3. [CrossRef]

16. Gasparyan AY, Ayvazyan L, Mikhailidis DP, Kitas GD. Mean platelet volume: a link between thrombosis and inflammation? Current Pharmaceutical Design. 2011;17:47-58. [CrossRef]

17. Kocak MZ, Aktas G, Erkus E, Duman TT, Atak BM, Savli H. Mean Platelet Volume to Lymphocyte Ratio as a Novel Marker for Diabetic Nephropathy. Journal of the College of Physicians and Surgeons--Pakistan: JCPSP. 2018;28:844-7. [CrossRef]

18. Bozlu G, Akar A, Durak F, Kuyucu N. Role of mean platelet volume-to-lymphocyte ratio in the diagnosis of childhood appendicitis. Archivos Argentinos de Pediatria. 2019;117:37580. [CrossRef]

19. Bilgin S, Aktas G, Zahid Kocak M, et al. Association between novel inflammatory markers derived from hemogram indices and metabolic parameters in type 2 diabetic men. The aging male : the official journal of the International Society for the Study of the Aging Male. 2019:1-5. [CrossRef]

20. Hudzik B, Szkodzinski J, Lekston A, Gierlotka M, Polonski L, Gasior M. Mean platelet volume-to-lymphocyte ratio: a novel marker of poor short- and long-term prognosis in patients with diabetes mellitus and acute myocardial infarction. Journal of Diabetes and Its Complications. 2016;30:1097102. [CrossRef]

21. Watanabe $Y$, Kawada M, Kobayashi B. Effect of insulin on murine megakaryocytopoiesis in a liquid culture system. Cell Structure and Function. 1987;12:311-6. [CrossRef] 